\title{
BADENIAN (MIDDLE MIOCENE) CALCAREOUS NANNOFOSSILS FROM PÂGLIŞA (CLUJ DISTRICT): BIOSTRATIGRAPHICAL IMPORTANCE
}

\author{
CARMEN CHIRA ${ }^{1}$, ERIKA SZABO ${ }^{2}$, CONSTANTIN IANOLIU ${ }^{3}$
}

\begin{abstract}
The calcareous nannofossils from the Middle Miocene (Badenian) formations from Pâglişa (Cluj district) are typical for the Lower and Middle Badenian, respectivelly Moravian and Wielician (or Langhian). The detailed study of the calcareous nannofossils from the Pâglişa section revealed the presence of the nannoplankton assemblages belonging to the NN5 and NN6 zones. They have been remarked 40 species of calcareous nannofossils. There are mentioned especially the most representative species and their biostratigraphical significance.
\end{abstract}

KEYWORDS: Middle Miocene (Badenian), calcareous nannofossils, biostratigraphy, Pâglişa, Transylvanian Basin.

\section{LOCATION}

We analysed the calcareous nannofossils from the former tuff quarry from Peşterii Valley - Pâglişa (Cluj district). It is situated at about $60 \mathrm{~km}$ from ClujNapoca, on the road between Pănticeni and Dăbâca localities (Fig. 1). Peşterii Valley is situated east from Pâglişa, the road with the old quarry begin from the western border of the village.

\section{GEOLOGICAL SETTING}

In the studied area there are natural and artificial outcrops of Miocene sedimentary formations represented by the Hida Formation. The Hida Formation (Ottnangian) contains an alternance of marls and sandstones with lenticular interbedded conglomerates. These deposits outcrop on the right side of Peşterii Valley, Morăului Valley and Pâglişei Valley, being represented by polygene microconglomerates, sandstones, sands, clays and sandy marls. The upper part of that formation, respectivelly the contact with the Dej Formation do not outcrop on the Peşterii Valley section.

The Dej Formation (Early Badenian) (Popescu, 1970) is transgressivelly disposed on the Hida Formation.

On the Peşterii Valley section the lithologic sequences of this formation contain an alternance of tuffs and Globigerina marls with an about $40 \mathrm{~m}$ vertical extent (Tab. 1).

1,2,3 "Babeş-Bolyai" University, Department of Geology, Str. Kogălniceanu 1, 3400 Cluj-Napoca, Romania. 


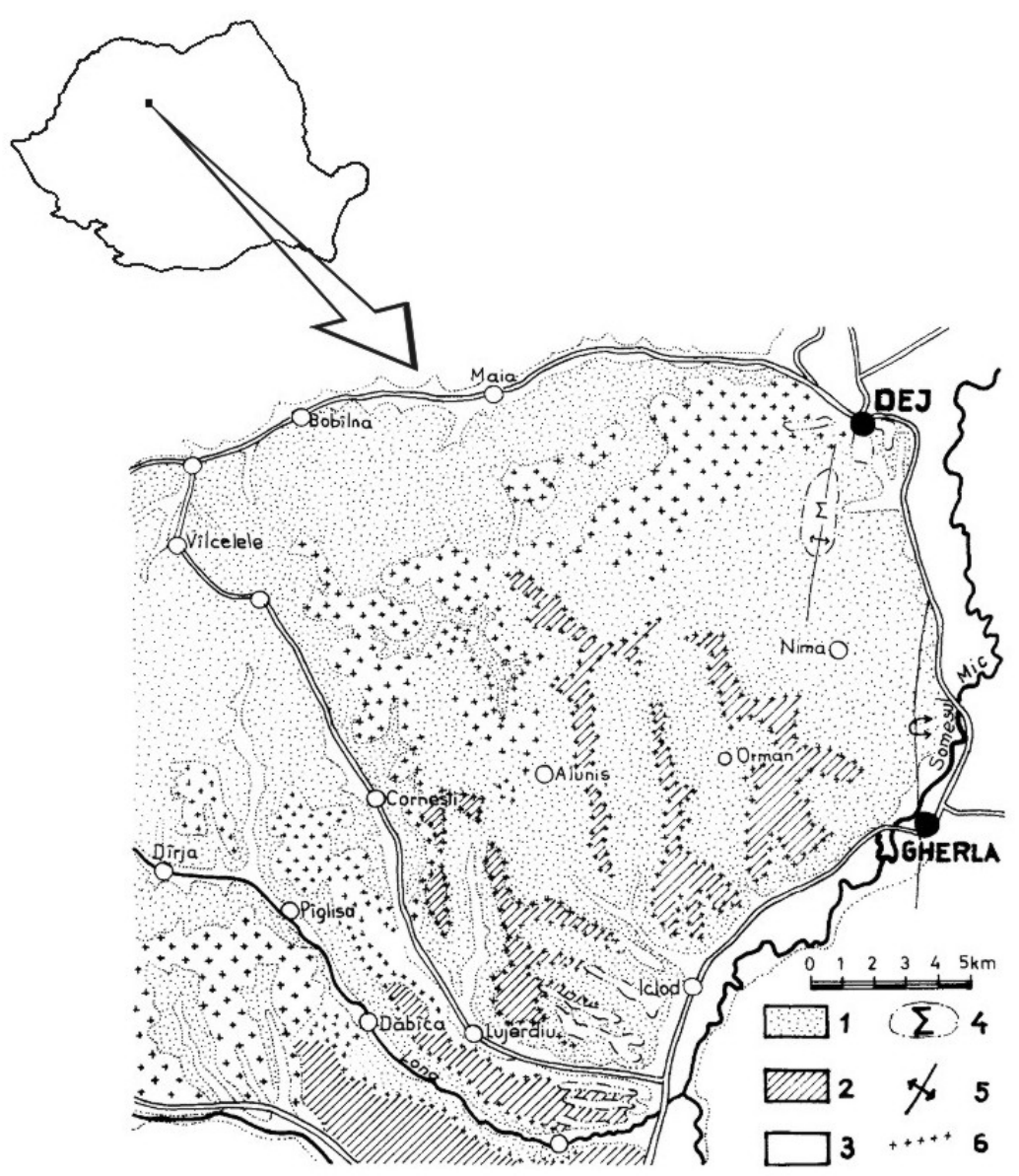

Fig. 1. Location and geological map (after Saulea et al., 1968) of the studied area. Legend: 1. Lower and Middle Badenian deposits; 2. Upper Badenian deposits;

3. Quaternary deposits; 4 . Salt dyapir; 5 . Antincline axe; 6. Tuff levels.

The tuffs horizons are delimited on west by the Pâglişei Valley, on east by the Corneşti Valley, on north by the Borcău Brook and on south they are extended to the Dăbâca locality. They occur on a large area on Peşterii Valley, Morăului Valley, Pâglişei Valley and Rea Valley.

The tuffs are dominated by vitroclastic and cristaloclastic petrofacies on the base of the section while in the upper part, the vitro-cristaloclastic type dominate. Szabo (1999) mentioned a tetrasequential volcanoclastic succesion.

In the upper part of the formation marine - lagunar deposits with compact fine and grob marls, clays and rarely sandstones and fine sands belonging to the Mireş Formation (Middle - Upper Badenian) (Upper Langhian - Lower Serravalian) occur. Lentiliform interbedded of white compact gypsum, with a width of $70-80 \mathrm{~cm}$ also occur. The marls with evaporites occur in the upper part of the Peşterii Valley and in the tuff quarry (Szabo, 1999). 


\section{BADENIAN CALCAREOUS NANNOFOSSILS ASSEMBLAGES: GENERAL CONSIDERATIONS AND RESULTS FROM PÂGLIŞA}

The calcareous nannoplankton assemblages, typical for Lower and Middle Badenian (or Langhian) - Moravian and Wielician belong to NN5 - Sphenolithus heteromorphus and NN6 - Discoaster exilis zones (after Martini's zonation, 1971).

Within the entire Central Paratethys, Badenian starts with the NN5 zone, while Langhian starts with the upper part of the NN4 - Helicosphaera ampliaperta. The Upper Badenian was correlated with Serravalian up to the medium levels of the latter. It is considered that Kossovian can be correlated either with the NN6 and part of the NN7 zone or with the NN6 zone (Rögl, 1996, 1997; Mărunțeanu, 1991; Mărunțeanu \& Chira, 1998; Chira, 1999; Chira \& Mărunțeanu, 2000; Mărunțeanu et al., 2000; Mészáros, 1991, 1995; Nicorici \& Mészáros, 1994, a. o.).

The NN5 - Sphenolithus heteromorphus zone was defined by Bramlette \& Wilcoxon (1967) between the last occurrence of Helicosphaera ampliaperta and the last occurrence of Sphenolithus heteromorphus. It is noticeable the domination of Discoaster deflandrei species within the lower part of the zone. The elliptical forms of Calcidiscus macintyrei and Calcidiscus leptoporus centrovalis become common and, within the upper part of the zone, the first occurrence of Triquetrorhabdulus rugosus is noted.

Bukry (1973) mentioned the first occurrence of Sphenolithus abies within the Sphenolithus heteromorphus zone. The first forms of Reticulofenestra pseudoumbilicus are noticed in this zone.

The NN5 zone has also the following subzones (Mărunțeanu \& Chira, 1998; Mărunțeanu et al., 2000):

- NN5a: the Geminilithella rotula (= Calcidiscus annula) subzone;

- NN5b: the Helicosphaera wallichii subzone.

The Discoaster exilis (NN6) zone was defined by Hay (1970) (emend. Martini, 1974) between the last occurrence of Sphenolithus heteromorphus - the first occurrence of Discoaster kugleri and/or the last occurrence of Cyclicargolithus floridanus. C. floridanus is less abundent near the upper part of the zone and it is replaced by the abundent Reticulofenestra pseudoumbilicus.

The calcareous nannoplankton determined from Pâglişa section (Peşterii Valley), belongs to the NN5 and NN6 zones and contains about 40 species (Tab 2).

By analyzing the species distribution of the 34 samples, we have noticed, the occurrence of Discoaster brouweri (PI. III, fig. 4) in sample 12 as well as the form Helicosphaera wallichii (PI. I, figs. 6a, 6b) in sample 19 within the first half of the lower part of the section. The two taxa occur almost simultaneously in the upper part of Dej Formation, respectively the upper part of the NN5 zone.

We have also noticed the even earlier occurrence of Sphenolithus abies species in sample 2 and Triquetrorhabdulus cf. farnsworthii (PI. III, fig. 7) and/or Triquetrorhabdulus rugosus (samples 3/9) (PL. III, fig. 6) which would belong to the same bioevent, corresponding to the upper part of the NN5 zone. Also, Helicosphaera walbersdorfensis (PI. I, figs. 5a, 5b) shows up from sample $1 \mathrm{~b}$ on.

Considering the possible division of the NN5 zone in subzone NN5a (Geminilithella rotula $=$ Calcidiscus annula) and NN5b (Helicosphaera wallichii) (Mărunțeanu in Mărunțeanu et al., 2000) we can see that the Calcidiscus annula 
species (PI. II, figs. 1a, 1b) appears in the entire profile and Helicosphaera wallichii only in sample 19. The occurrence of the latter, as well as the abundance of Discoaster broweri indicates the proximity of the NN5 - NN6 zone boundary.

Frequent discoasters appear in sample 25. In samples 31, 32, 33, the assemblages with Discoaster broweri, Reticulofenestra pseudoumbilicus and Reticulofenestra gelida prevail.

Discoaster exilis (PI. III, fig. 1) appears from sample 2 up to the penultimate one (33).

Its first occurrence was noticed from the bottom of the NN5 zone (Moravian) on. Wielician is correlated with the upper part of the NN5 zone and the lower part of the NN6 zone (possibly beginning with the first occurrence of Discoaster brouweri).

Kossovian generally correspond to the largest part of the NN6 zone, its upper boundary being influenced by the dissappearance of Cyclicargolithus floridanus. Sphenolithus heteromorphus (PI. I, figs. 1a, 1b) - index species for NN5 shows up to the sample 29, inclusively. In the last sample it is not noticed anymore. Here, we frequently notice $D$. brouweri, $S$. abies, $T$. rugosus, $H$. walbersdorfensis, H. wallichii and, sometimes, C. leptoporus (PI.II, fig. 7) and C. macintyrei (PL. II, fig. 4).

Discoaster brouweri, Reticulofenestra pseudoumbilicus and Reticulofenestra gelida prevail in sample 32. All these species show together with the NN6 zone index - Discoaster exilis.

Obviously, the NN6 zone starts at least from sample 31. We have to mention the fact that there was no Discoaster deflandrei, regarded as dominant within the basis of NN5.

Triquetrorhabdulus rugosus occurs frequently from sample 9 on and its first occurrence is considered to be the upper part of the NN5 zone.

From the bottom of the Pâglişa profile up to its top we have frequently come across Cyclicargolithus floridanus (PI. II, figs. 5a, 5b).

Calcareous dinoflagellates represented by thoracospherids are also sometimes present in the investigated samples.

\section{CONCLUSIONS}

The deposits belonging to the Dej Formation from the Pâglişa Valley contain calcareous nannoplankton assemblages belonging to NN5 and NN6 zones (partim).

The argumentation is based on: the presence of the index fossil Sphenolithus heteromorphus (from the sample nr. 1 to 30) and the abundant presence of the discoasterids: Discoaster exilis - the index species for NN6, and $D$. brouweri, a. o. species that indicate the presence of NN6 zone in the upper part of the section from Pâglişa (samples 31 - 34).

To conclude, within the Pâglişa profile, we determined 40 calcareous nannofossils species. Only 13 of these have been mentioned before (Mészáros in Mészáros \& Şuraru, 1991). These deposits have been considered belonging only to NN5 zone (Mészáros in Mészáros \& Şuraru, 1991).

The nannofossils assemblages allowed us to attribute the investigated deposits from the Dej Formation to the NN5 and to the NN6 (partim) zones. Due to the existence of Wielician gypsum over the deposits successions attributed to Dej 
Formation we can conclude that the gypsum could be enclosed within the NN6 zone.

Tab. 2.

The distribution of the calcareous nannofossils, at Pâglişa

(in systematical order, after Young \& Bown, 1997).

\begin{tabular}{|c|c|c|}
\hline NANNOFOSSIL SPECIES & $\begin{array}{c}\text { Moravian } \\
1-30\end{array}$ & $\begin{array}{c}\text { Wielician } \\
31-34\end{array}$ \\
\hline Helicosphaera carteri (WALLICH, 1877) KAMPTNER (1954) & $\bar{X}$ & $\bar{X}$ \\
\hline Helicosphaera walbersdorfensis MÜLLER (1974) & $\mathrm{X}$ & $\mathrm{X}$ \\
\hline Helicosphaera wallichii (LOHMANN, 1902) OKADA \& MCINTYRE (1977) & $\mathrm{X}$ & $\mathrm{X}$ \\
\hline Pontosphaera multipora (KAMPTNER, 1948) ROTH (1970) & $\mathrm{X}$ & $\mathrm{X}$ \\
\hline Syracosphaera histrica KAMPTNER (1941) & $\mathrm{X}$ & $\mathrm{X}$ \\
\hline Rhabdosphaera procera MARTINI (1969) & $\mathrm{X}$ & \\
\hline Rhabdosphaera pannonica BALDI-BEKE (1960) & $\mathrm{X}$ & $\mathrm{X}$ \\
\hline Rhabdosphaera sicca STRADNER in BACHMANN et al., 1963 & $\mathrm{X}$ & \\
\hline Rhabdosphaera poculi (BONA \& KERNERNE SUMEGI 1964) MÜLLER (1974) & $\mathrm{X}$ & \\
\hline Rhabdosphaera claviger MURRAY \& BLACKMAN (1898) & $\mathrm{X}$ & $\mathrm{X}$ \\
\hline Cyclicargolithus floridanus (ROTH \& HAY in HAY et al., 1967) BUKRY (1971) & $\mathrm{X}$ & $\mathrm{X}$ \\
\hline Cyclicargolithus abisectus (MÜLLER, 1970) WISE (1973) & $\mathrm{X}$ & \\
\hline Reticulofenestra pseudoumbilicus (GARTNER, 1967) GARTNER (1969) & $\mathrm{X}$ & $\mathrm{X}$ \\
\hline Reticulofenestra gelida (GEITZENAUER, 1972) BACKMAN (1978) & $\mathrm{X}$ & $\mathrm{X}$ \\
\hline Reticulofenestra minuta ROTH (1970) & $\mathrm{X}$ & $\mathrm{X}$ \\
\hline Reticulofenestra minutula (GARTNER, 1967) HAQ \& BERGGREN (1978) & $\mathrm{X}$ & \\
\hline Coccolithus miopelagicus BUKRY (1971) & $\mathrm{X}$ & $\mathrm{X}$ \\
\hline Coccolithus pelagicus (WALLICH, 1877) SCHILLER (1930) & $\mathrm{X}$ & \\
\hline $\begin{array}{l}\text { Calcidiscus leptoporus (MURRAY \& BLACKMAN, 1898) LOEBLICH \& TAPPAN } \\
(1978)\end{array}$ & $\mathrm{X}$ & $\mathrm{X}$ \\
\hline $\begin{array}{l}\text { Calcidiscus macintyrei (BUKRY \& BRAMLETTE, 1969) LOEBLICH \& TAPPAN } \\
\text { (1978) }\end{array}$ & $\mathrm{X}$ & $\mathrm{X}$ \\
\hline Calcidiscus cf. pataecus GARTNER (1967) & & $\mathrm{X}$ \\
\hline Geminilithella rotula (KAMPTNER, 1956) BACKMAN (1980) & $\mathrm{X}$ & $\mathrm{X}$ \\
\hline Umbilicosphaera jafari MÜLLER (1974) & $\mathrm{X}$ & $\mathrm{X}$ \\
\hline $\begin{array}{l}\text { Holodiscolithus macroporus (DEFLANDRE in DEFLANDRE \& FERT, 1954) } \\
\text { ROTH (1970) }\end{array}$ & $\mathrm{X}$ & $\mathrm{X}$ \\
\hline Braarudosphaera bigelowii (GRAN \& BRAARUD, 1935) DEFLANDRE (1947) & $\mathrm{X}$ & $\mathrm{X}$ \\
\hline Micrantolithus vesper DEFLANDRE in DEFLANDRE \& FERT (1954) & $\mathrm{X}$ & \\
\hline Discoaster variabilis MARTINI \& BRAMLETTE (1963) & $\mathrm{X}$ & $\mathrm{X}$ \\
\hline Discoaster exilis MARTINI \& BRAMLETTE (1963) & $\mathrm{X}$ & $\mathrm{X}$ \\
\hline Discoaster musicus STRADNER (1959) & $\mathrm{X}$ & $\mathrm{X}$ \\
\hline Discoaster deflandrei BRAMLETTE \& RIEDEL (1954) & $X$ & \\
\hline Discoaster brouweri TAN (1927) emended BRAMLETTE \& RIEDEL (1954) & $\mathrm{X}$ & $\mathrm{X}$ \\
\hline Discoaster cf. bellus BUKRY \& PERCIVAL (1971) & & $\mathrm{X}$ \\
\hline Triquetrorhabdulus farnsworthii LIPPS (1969) & $\mathrm{X}$ & \\
\hline Triquetrorhabdulus rugosus BRAMLETTE \& WILCOXON (1967) & $\mathrm{X}$ & $\mathrm{X}$ \\
\hline Triquetrorhabdulus sp. & $\mathrm{X}$ & \\
\hline Sphenolithus heteromorphus DEFLANDRE (1953) & $\mathrm{X}$ & \\
\hline Sphenolithus abies DEFLANDRE in DEFLANDRE \& FERT (1954) & $X$ & $\mathrm{X}$ \\
\hline Sphenolithus neoabies BUKRY \& BRAMLETTE (1969) & $\mathrm{X}$ & \\
\hline $\begin{array}{l}\text { Sphenolithus moriformis (BRÖNNIMANN \& STRADNER, 1960) BRAMLETTE \& } \\
\text { WILCOXON (1967) }\end{array}$ & $\mathrm{X}$ & $\mathrm{X}$ \\
\hline Thoracosphaera sp. & $\mathrm{X}$ & $\mathrm{X}$ \\
\hline
\end{tabular}




\section{CARMEN CHIRA, ERIKA SZABO, CONSTANTIN IANOLIU}

\section{REFERENCES}

1. Bramlette, M. N., Wilcoxon, J. A., 1967, Middle Tertiary calcareous nannoplankton of the Cipero section, Trinidad, W. I. Tulane Studies Geology, 5, p. 93 - 131.

2. Bukry, D., 1973, Low-latitude coccolith biostratigraphic zonation. Initial Reports DSDP 15, p. $685-703$

3. Chira, C., 1999, Middle Miocene calcareous nannoplankton from the western Transylvanian Basin, Romania: biostratigraphy, taxonomy and palaeoecology. Studia Univ. Babes-Bolyai, Geol., XLIV, 2, p. 3 - 75, 6 figs., 2 tabs., 7 pls.

4. Chira, C., Mărunțeanu, M., 2000, Calcareous nannofossils and dinoflagellates from the Middle Miocene of the Transylvanian Basin. Abstract. $8^{\text {th }}$ INA (International Nannoplankton Association) Conf., Bremen. Journal of Nannoplankton Research, 22/2, p. 89 - 90.

5. Hay, W. W., 1970, Calcareous nannofossils from cores recovered on Leg 4. Initial Rep. DSDP, 4, p. $455-501$.

6. Martini, E., 1971, Standard Tertiary and Quaternary Calcareous Nannoplankton Zonation. Proceedings of the II Planktonic Conference, Roma, 1970, A. Farinacci, ed., Ed. Tecnoscienza, p. 739 - 785, Rome.

7. Mărunțeanu, M., 1991, Distribution of the Miocene Calcareous Nannofossils in the Intra- and Extra- Carpathian Areas of Romania. Proced. IV. INA Conf., Knihovnicka ZPN, 14 b, 2, p. 247 - 261, 1 fig., 4 tab., Prague.

8. Mărunțeanu, M., Chira, C., 1998, Marine middle Miocene calcareous nannoplankton: a comparative study of the Subcarpathians and Transylvanian Basin. Abstract. XVI. CarpathoBalkan Congress, Vienna, 1998.

9. Mărunțeanu, M., Crihan, M., Chira, C., 2000, Badenian nannofossil zonation - the Carpathian area, Romania. Acta Palaeontologica Romaniae, II, p. 261 - 267, 3 figs., ClujNapoca.

10. Mészaros, N., 1991, Nannofossil Zones in the Paleogene and Miocene Deposits of the Transylvanian Basin. Proced. IV. INA Conf., Knihovnicka ZPN, 14 b, 2, p. 87 - 92, 3 fig., Prague.

11. Mészaros, N., Şuraru, N., 1991, Le nannoplancton et les foraminiferes du Complexe du Tuf de Dej de la region Şoimeni - Pâglişa. In vol. The Volcanic Tuffs from the Transylvanian Basin, p. 349 - 356, Cluj-Napoca.

12. Mészaros, N., 1995, Nannoplankton Zones in the Volcanic tuffs of the Transylvanian Basin (Miocene). Abstract. Journal of Nannoplankton Research, 17, 2, p. 75, 6th INA (International Nannoplankton Association) Conf. - 1995, Copenhagen.

13. Nicorici, E., Mészaros, N., 1994, Delimitations et subdivisions du Miocene en Europe et leur applications sur certaines regions de Roumanie. In vol. The Miocene from the Transylvanian Basin, p. 5 - 18, 2 fig., Cluj-Napoca.

14. Popescu, G., 1970, Planktonic Foraminiferal Zonation in the Dej Tuff Complex. Rev. Roum. Géol., Géoph., Géogr., ser. Geol., 14/2, p. 189 - 203, Bucureşti.

15. Rögl, F., 1996, Stratigraphic correlation of the Paratethys Oligocene and Miocene. Mitt. Ges. Geol. Bergbaustud. Österr., 41, p. 65 - 73, 1 Tab., Wien.

16. Rögl, F., 1997, Palaeogeographic Considerations for Mediterranean and Paratethys Seaways (Oligocene to Miocene). Ann. Naturhist. Mus. Wien, 99 A, p. 279 - 310, 10 pl., 1 tab, Wien.

17. Saulea, E. et al., 1968, Harta geologică 1:200.000, foaia Cluj. Bucureşti.

18. Szabo, E., 1999, Studii paleomagnetice şi stratigrafice asupra Formațiunii de Dej. Lucrare de licență, Univ. Babeş-Bolyai,Cluj-Napoca, 57 p., 5 pl., 8 anexe.

19. Young, J., R., Bown, P. R., 1997, Cenozoic calcareous nannoplankton classification. Journal of Nannoplankton Research, 19, 1, p. $15-47$. 


\section{Plate I:Fig.:}

1 - Sphenolithus heteromorphus Deflandre. 1a - NII; 1b - N+; x 2000

2 - Sphenolithus neoabies Deflandre. $2 \mathrm{a}-\mathrm{NII}, 2 \mathrm{~b}-\mathrm{N}+; \times 2000$.

3 - Sphenolithus cf. neoabies Bukry \& Bramlette 3a - NII, 3b - N+; 2000.

4 - Sphenolithus moriformis (Brönnimann \& Stradner) Bramlette \& Wilcoxon, Coccolithus pelagicus (Wallich) Schiller. 4a - NII, 4b - N+; x 2000.

5 - Helicosphaera walbersdorfensis Müller. 5a - NII, 5b - N+; x 2000.

6 - Helicosphaera wallichii (Lohmann) Okada \& Mclntyre. 6a - NII, 6b - N+; x 2000.

\section{Plate II:Fig.:}

1 - Geminilithella rotula (Kamptner) Backman (= Calcidiscus annula (Cohen)). 1a NII, $1 \mathrm{~b}-\mathrm{N}+; \mathrm{x} 2000$.

2 - Cyclicargolithus floridanus (Roth \& Hay) Bukry. 2a - NII, 2b - N+; x 2000.

3 - Umbilicosphaera jafari Müller. 3a - NII, 3b - N+; x 2000.

4 - Calcidiscus cf. macintyrei (Bukry \& Bramlette) Loeblich \& Tappan. NII; x 2000.

5 - Calcidiscus cf. pataecus Gartner. NII; x 2000.

6 - Cyclicargolithus cf. abisectus (Müller) Wise. 6a - NII, 6b - N+; x 2000.

7 - Calcidiscus leptoporus (Murray \& Blackman) Loeblich \& Tappan. 7a - NII, 7b $\mathrm{N}+; \mathrm{x} 2000$.

\section{Plate III:Fig.:}

1 - Discoaster exilis Martini \& Bramlette NII; x 2000.

2 - Discoaster variabilis Martini \& Bramlette. NII; x 2000.

3 - Discoaster musicus Stradner. NII; x 2000.

4 - Discoaster brouwerii Tan emend. Bramlette \& Riedel. NII; x 2000.

5 - Micrantolithus vesper Deflandre in Deflandre \& Fert. 5a - NII, 5b - N+; x 2000.

6 - Triquetrorhabdulus rugosus Bramlette \& Wilcoxon. NII; x 2000.

7 - Triquetrorhabdulus cf. farnsworthii Lipps. NII; x 2000.

8 - Reticulofenestra minuta Roth. 8a - NII, 8b - N+; x 2000.

9 - Thoracosphaera sp. 9a - NII, 9b - N+; x 2000.

\section{Plate IV:Fig.:}

1 - Rhabdosphaera procera Martini. NII; x 2000.

2 - Rhabdosphaera poculi (Bóna \& Kernerné) Müller. 2a - NII, 2b - N+; 2000.

3 - Rhabdosphaera pannonica Baldi - Beke. NII; x 2000.

4 - Syracosphaera histrica Kamptner. 4a - NII, 4b - N+; x 2000.

5 - Pontosphaera multipora (Kamptner). 5a - NII, 5b - N+; x 2000.

6 - Braarudosphaera bigelowii (Gran \& Braarud) Deflandre. 6a - NII, $6 \mathrm{~b}-\mathrm{N}+; \mathrm{x}$ 2000.

7 - Coccolithus miopelagicus Bukry. 7a - NII, 7b N+; x 2000. 


\section{Plate I}
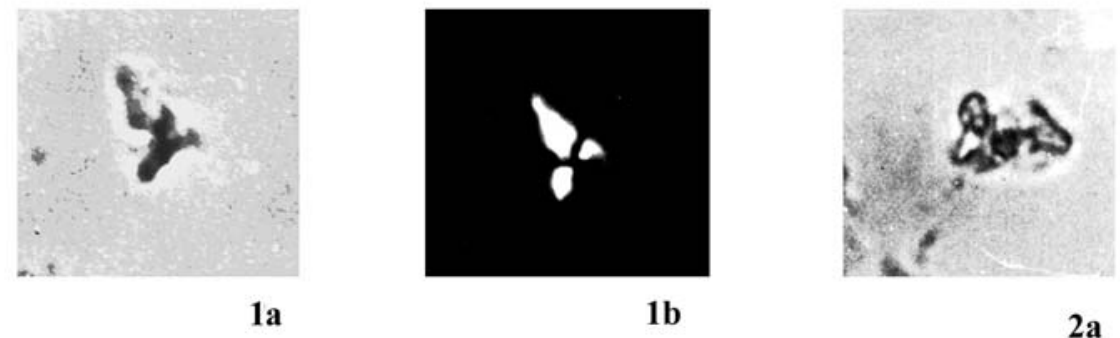

$1 b$

2a
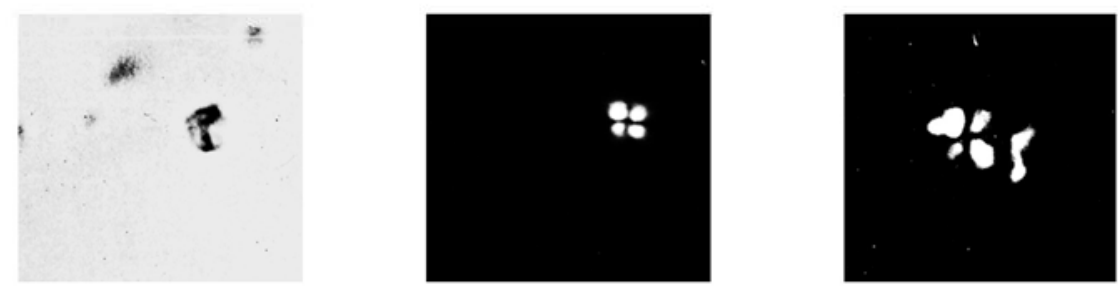

3b

2b
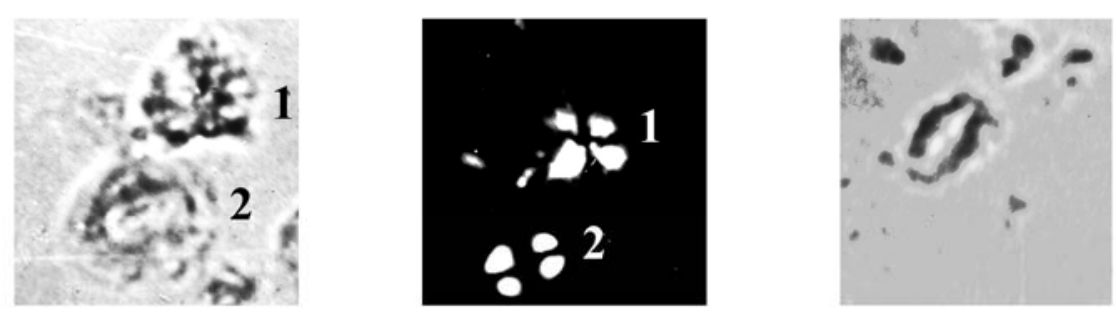

$4 a$

4b

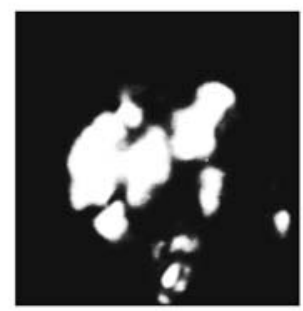

$6 b$

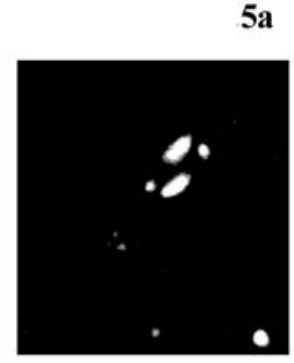

$\mathbf{5 b}$ 


\section{Plate II}
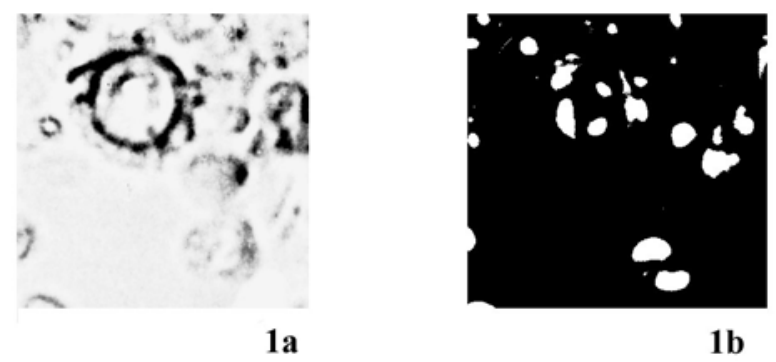

1b
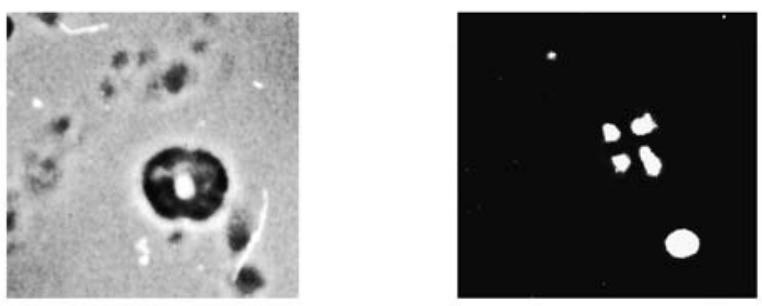

3b
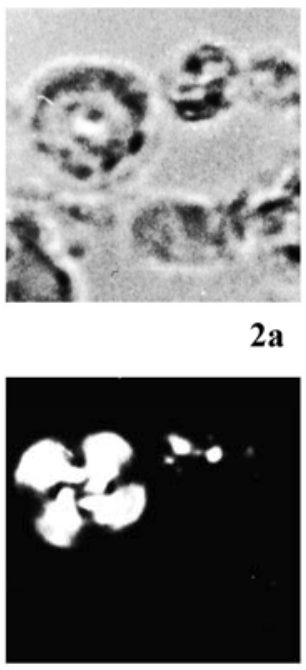

$3 \mathbf{a}$
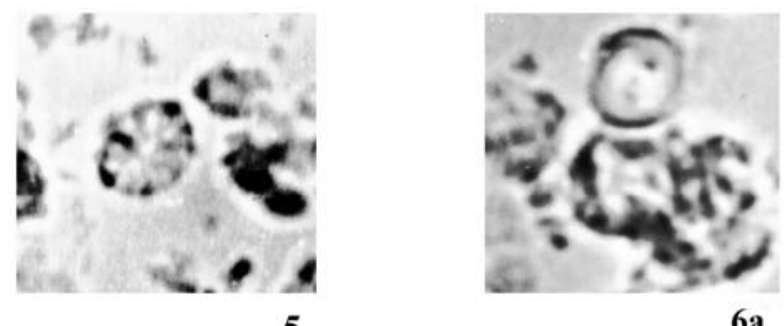

4

5
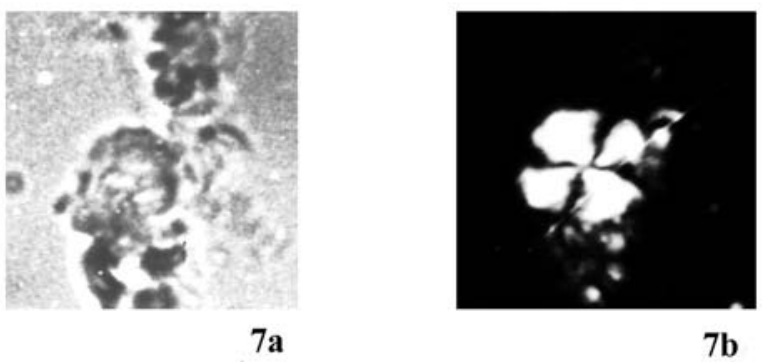

7b

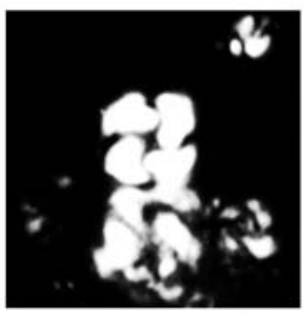

$6 b$ 


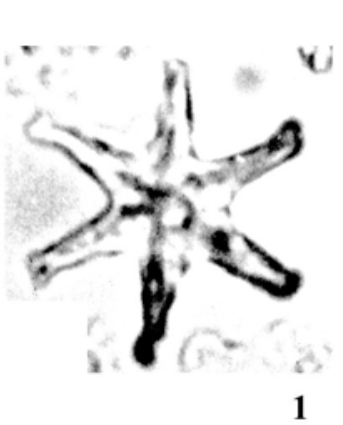

Plate III
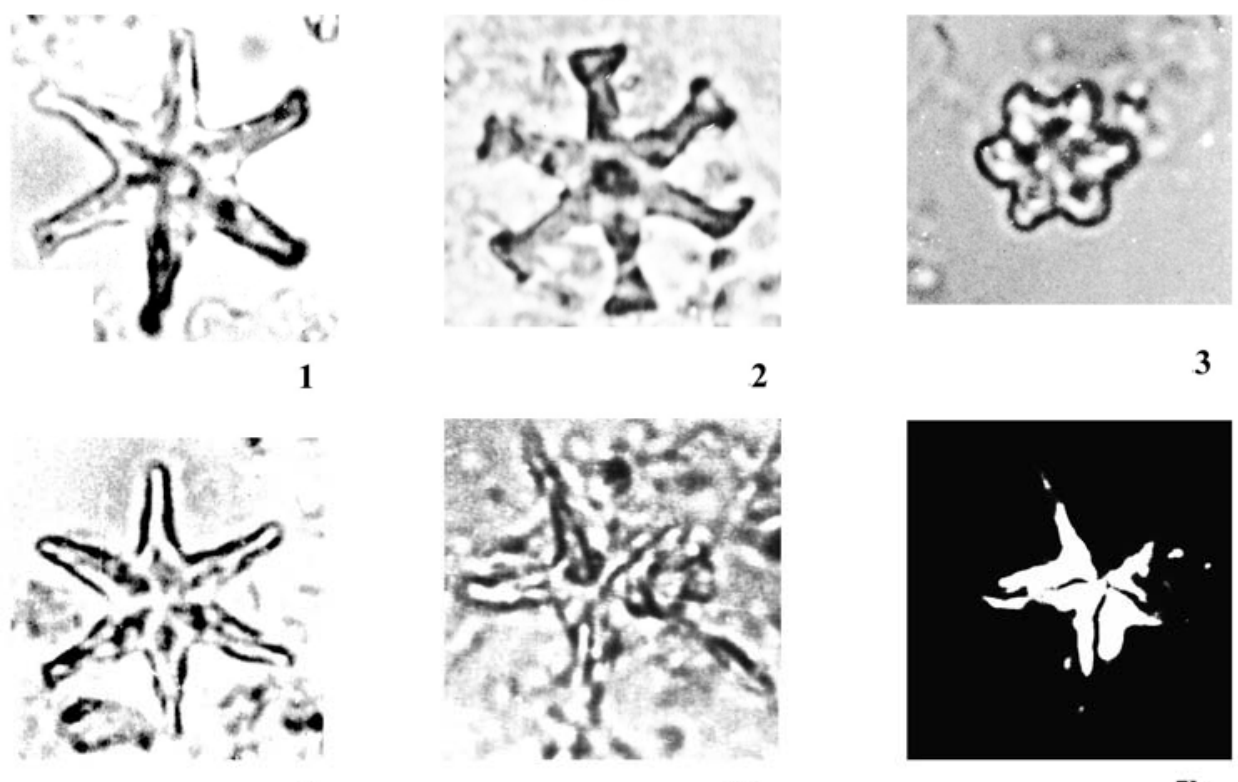

4

$5 a$
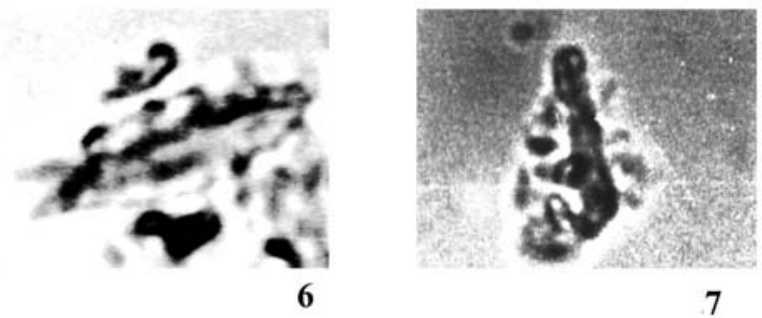

$5 \mathbf{b}$

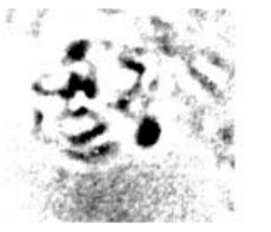

9 a

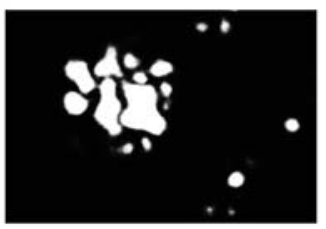

9 b
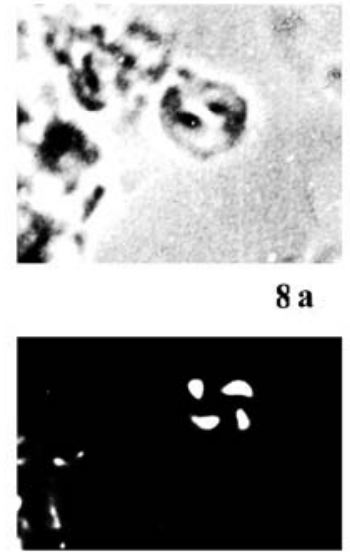

$8 b$ 


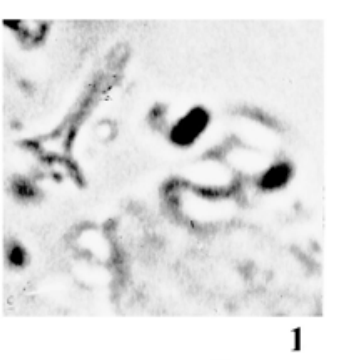

\section{Plate IV}
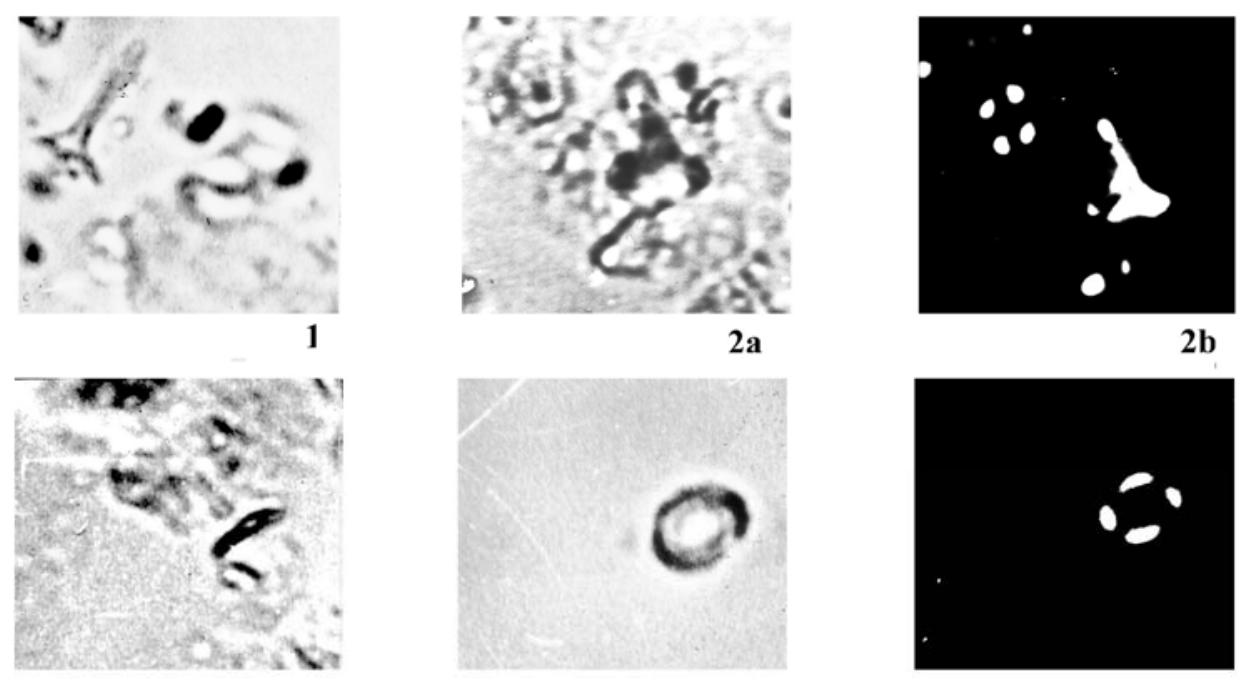

3

4a

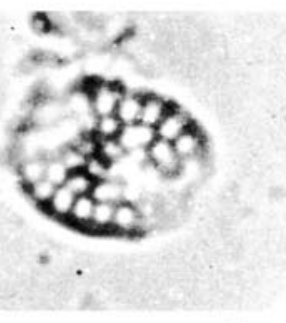

$5 \mathbf{a}$

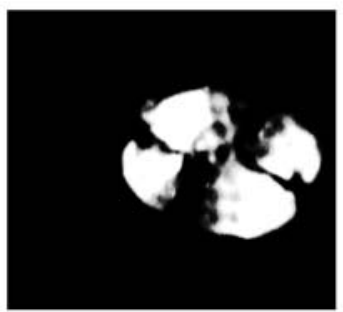

$4 b$

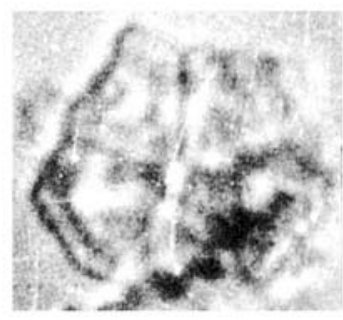

$5 \mathbf{b}$

6a
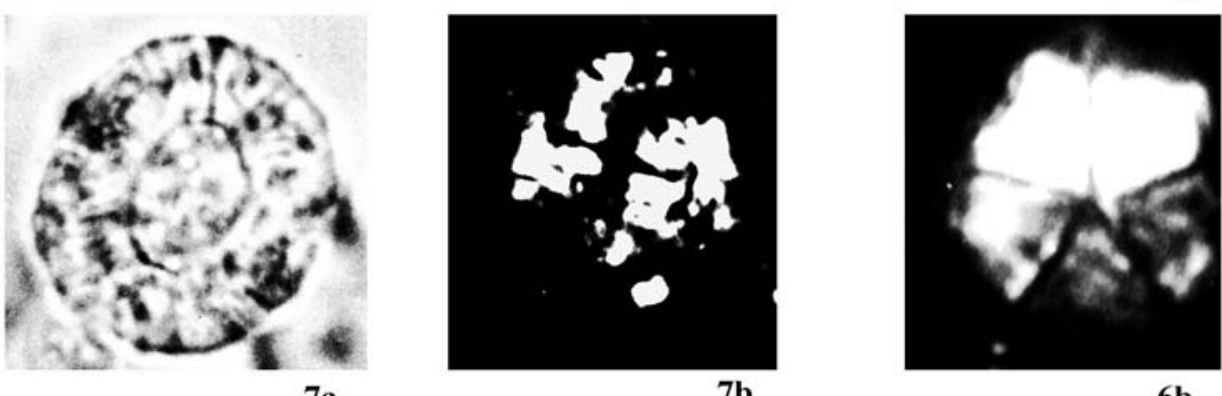

6b 